\title{
Financial Literacy among Women - Indian Scenario
}

\author{
Chetna Singh", Raj Kumar \\ Institute of Management Studies, Banaras Hindu University, India
}

Copyright $\bigcirc 2017$ by authors, all rights reserved. Authors agree that this article remains permanently open access under the terms of the Creative Commons Attribution License 4.0 International License

\begin{abstract}
One of the biggest challenges of our country is women empowerment which can only be attained by making women educated, finance liberated and independent. Financial literacy can be understood as the ability to know how money works in a normal course of action. Specifically it refers to the set of skills and knowledge that allows an individual to make informed and effective decisions with all of their financial resources. In India, virtually women are the main spender of the family whereas the men are the principal earner of the family. Although women's access to financial services has increased substantially faster in the past 10 years, their ability to exploit this access is often still limited by the disadvantages they experience because of their gender. Women are good at budgeting and managing household expenses but many women take their steps back when it comes to take larger financial decisions and they generally leave it to their spouses, fathers, brothers, etc, believing them to be financial experts. A minimum basic level of financial literacy is very essential for every woman so that they can live their life according to their own choices hence contributing the healthy and prosperous life of their family as a whole. Women have enormous potential to contribute towards the growth of the economy hence a financially independent women can be a great source of economic development. The purpose of this study was to give an overview about the financial literacy among women in developing country like India.
\end{abstract}

Keywords Financial Literacy, Women Empowerment, Financial Decisions and Economic Development

\section{Introduction}

One of the biggest challenges for our nation is women empowerment which can only be attainable when they will be educated and financially literate and independent. A financially independent individual is able to make intellectual judgments and take effective choices regarding the usage and management of money (Noctor et al., 1992). It is very encouraging to see that today women are at par with men in all fields but when it comes to financial decision-making, they are still dependent on the male members of their family.

Since ages, this world has been a male dominated world, where men run the society and women follow him. Women are the important constituent of our society; rather they are the basis of human kind. It is rightly said that if we made a women literate whole family becomes literate. In 2015, the world literacy was $86.3 \%$, among which $82.7 \%$ of women were literate. The Indian scenario is bit grim where among $72 \%$ literate persons, $62.8 \%$ women were literate. ("Literacy Statistics Metadata Information Table". UNESCO Institute for Statistics. September 2015). These women, not only play an important role socially, but economically also. In India, virtually women are the main spender of the family whereas the men are the principal earner of the family. In earlier times the status of women was inferior compared to men as they are considered to be the perfect homemaker in the world, who is supposed to do the work of home and raise the family only. Though they had a higher status in scriptures, they are preached in different names like Goddess Durga, Goddess Saraswati, and Goddess Kali and so on. In modern times too their condition is not improved much, they were always under the influence of their parents before marriage and their husband after marriage. However the status of women in the modern time starts improving. Now women were given freedom \& right such as freedom of expression \& equality as well as the right to be educated. At this period various prestigious positions were held by women. However, some problems such as domestic violence, dowry, sex selective abortion, are still prevalent.

The government has taken various steps for empowering women. In this regard the government has established The Ministry for Women \& Child Development as a department of the Ministry of Human Resource Development in the year 1985 to make the holistic development of women and children in the country and in the year 2006 the department was given the status of a Ministry. The ministry has levied with the power to formulate programs, policies and plans; coordinate and supervised the efforts of governmental and non- governmental organizations working in the field of women empowerment. The ministry is also executing an 
exclusively integrated scheme for the empowerment of women named as Swayamsidha Program with core motive of establishing women's self- help group which will help women to have increased access to all kinds of resources which they normally denied, in addition to this, helps in increasing their awareness and skills thus actually feel them empowered. Although women's access to financial services has increased substantially faster in the past 10 years, their ability to exploit this access is often still limited by the disadvantages they experience because of their gender.

Same is the situation with the financial literacy. There is a gender gap between men and women in almost every country in case of financial literacy as well. Worldwide, there is a five-point gender gap, with $65 \%$ of men not being financially literate compared with $70 \%$ of women. In India, the gap is wider with $73 \%$ of men and $80 \%$ of women not being financially literate (S\&P survey, Dec 16 2015). While women are less likely to provide correct answers to the financial literacy questions, they are also more likely to indicate that they "don't know" the answer.

Women are good at budgeting and managing household expenses but many women take their steps back when it comes to take larger financial decisions and they generally leave it to their spouses, fathers, brothers, etc, believing them to be financial experts. Women are less experienced about the basic aspects of financial life. Usually they leave everything to their spouses not realizing the trouble they might have to suffer in the event of widowhood, divorce, spouse's incapacitation, etc. A minimum basic level of financial literacy is very essential for every woman so that they can live their life according to their own choices and take their saving \& investment decisions in more effective and efficient manner hence contributing the healthy and prosperous life of their family as a whole. The purpose of this study was to give an overview about the financial literacy among women in developing country like India.

The purpose of this study was to give an overview about the financial literacy among women in developing country like India. This study was based on the concepts retrieved from the various facts and figures and previous studies.

\section{Financial Literacy}

Financial literacy can be understood as the ability to know how money works in a normal course of action. Specifically it refers to the set of skills and knowledge that allows an individual to make informed and effective decisions with all of their financial resources. Financial literacy is directly related to the wellbeing of an individual and society as a whole, since it helps an individual to manage their personal financial matters like savings, investments, tax planning, retirement planning, etc. and enables them to understand how more money can be generated and used in more effective and efficient manner.

Noctor et.al (1992) defined financial literacy as 'the ability to make informed judgments and to take effective decisions regarding the use and management of money'.

Moore (2003) stated that "Individuals are considered financially literate if they are competent and can demonstrate they have used knowledge they have learned. Financial literacy cannot be measured directly so proxies must be used. Literacy is obtained through practical experience and active integration of knowledge. As people become more literate they become increasingly more financially sophisticated and it is conjectured that this may also mean that an individual may be more competent".

Mandell (2007) defined financial literacy as "The ability to evaluate the new and complex financial instruments and make informed judgments in both choice of instruments and extent of use that would be in their own best long-run interests".

Lusardi (2008) define financial literacy as "Knowledge of basic financial concepts, such as the working of interest compounding, the difference between nominal and real values, and the basics of risk diversification".

The Organization for Economic Co-operation and Development (OECD) has defined financial literacy as "a combination of awareness, knowledge, skill, attitude and behaviour necessary to make sound financial decisions and ultimately achieve individual wellbeing".

As per Reserve Bank of India, financial literacy can broadly be defined as the capacity to have familiarity with an understanding of financial market products, especially reward and risks in order to make informed choices.

The National Financial Educators Council defines financial literacy as: "Possessing the skills and knowledge on financial matters to confidently take effective action that best fulfils an individual's personal, family and global community goals."

Although the definitions given by different organisations and authors are varied, some similar components in each financial literacy's definition are found. Each definitions of the financial literacy have focused on the importance of having the financial skill and knowledge to make informed decisions.

\section{Importance of Financial Literacy}

In today's scenario, emerging as well as developed economies has started giving very much focus on the level of financial literacy of their people. The financial system plays a very significant role in the development of any nation. Financial ignorance carries significant costs. Consumers who fail to understand the concept of interest compounding spend more on transaction fees, run up bigger debts, and incur higher interest rates on loans (Lusardi and Tufano, 2015; Lusardi and de Bassa Scheresberg, 2013). The consumers need to be financially literate to be able to understand the financial world and make well-informed decisions that will be profitable. The need for financial 
literacy in a country like India is because of:

\subsection{Increase in Life Expectancy}

Now a day, the people become more conscious about their health and improvements in health care services has increased the life expectancy in India, which results in a longer time to spend in retirement. This will certainly increases the need of financial planning such as savings for post-retirement, investment decisions, expanded insurance plans and provision for unexpected future eventualities. Only knowing the importance of financial planning is not enough, the individual must know how they can make their financial planning in better way so that their purposes could be achieved. For doing better financial planning one must know the basic concepts of money management like computation of compound interest, risk diversification etc. Hence focusing on the importance of having minimum level of financial literacy.

\subsection{Innovations in Financial Products/Services and Technological Development}

Liberalization, development in technology, deregulation and increased level of financial inclusion provides a wide range of financial products and services delivering through various channels thus providing consumers more choices to invest their savings. The available products are more complex in nature thus required some factors to be taken care of such as interest charged/ received, fees charged and level of risk involved etc. The greater opportunity available in financial products/services could only be utilized when one can have the better knowledge and must be aware about it. Since there is a wider range of options for savings one must have the skills to analyze which option is better for them and which will help them in accumulating their wealth.

The development in technology has changed the functioning of the financial markets and making the transactions speedier. Financial literacy helps the individual to make their financial decisions in more effective and efficient manner thus helping in wealth accumulation. Moreover, due to technological development now days almost every bank provides their services with the help of internet banking and also through various mobile apps thus providing ease in accessing the financial services. But only knowing this is not enough, one must have the skills and knowledge of using these apps, must have the skills to identify the authentic apps because these are not free from cyber theft. Hence, financial literacy becomes important.

\subsection{Shift in Risk}

The risk has been transferred from government and employer both to individuals. Now, one has to plan their financial security by themselves so that they can secure their future and may save their money for after retirement period. Every financial products/ services involves certain risk but due to increased complexities in the financial market the financial products/ services become more risky. Many times people are unaware of the risk they might have to face due to lack of financial knowledge and skills. Since the risk is shifted to individual only they have to be more alert in investing their money, managing their portfolios so that their money can be invested in such a manner that it help in their wealth accumulation as a whole. Most surveys show that a majority of workers are unaware of the risks they now have to face, and do not have sufficient knowledge or skill to manage such risks adequately, even if they are aware of them (OECD, 2008). So being aware only regarding financial market or product/ services may not fulfill the purpose, one must have the skills and knowledge to analyze the information available properly then only the investments in financial market proves to be profitable.

\subsection{Change in the Structure of the Family}

Earlier, in joint family the decisions were taken by the head of the family with the consent of every member and each and every one is accountable for that decision. The profit earned or the loss suffered was shared among everyone in the family, no one is solely responsible for profit or accountable for loss. Now days the structure of nuclear family increases the responsibilities of individuals in respect of spending, saving and investment. The conception of nuclear family appeared in the early twentieth century. The concept of Liberalisation, Privatisation and Globalisation opens the greater job opportunity which increases the mobility of an individual. For grabbing the better opportunities the individual starts moving from their native places and thus get separated from their whole family. Since the nuclear family consists of only husband, wife and their children so the responsibility of decision making is on the two persons only. The individual is only responsible for their decisions and may have to face consequences of their choice. Moreover, it becomes very important for parents to plan and invest adequately for their children's education because of increase in education costs. Individuals need to be financially literate so that they can make informed and accountable decisions.

\section{Review of Literature}

Annamaria Lusardi (2006) conducted a study on Planning and Financial Literacy: How Do women Fare? The objectives of the study were to examine the saving behavior of women, to analyse how women plan for retirement, tools $\&$ sources of information used for planning and to analyse the financial literacy of women. Study was conducted on 1,264 respondents, among which $60 \%$ are women who are of 50 yrs old or older and $64 \%$ are married. Regression method 
and multivariate analysis was used to know the importance of financial literacy and the relationship with planning in the total sample and among women only, and found that women had little financial literacy, retirement calculation was not an easy task particularly for women and they are much more rely on family, friends and advisers for their financial planning.

Martha Klatt, (2009), conducted a study on An Assessment of Women's Financial Literacy. Objective of the study was to identify the barriers preventing knowledge and understanding from being translated into actual behaviour, what resources are needed to provide women with financial information and whether there is a need for more resources and training programs on financial literacy for women. The study was conducted on 300 women aged 16 and above but only 167 women responded out of 300 . The mean, variance, and standard deviation were used for analysis and found that there are some barriers that women face in regards to financial matters, trends showing that women are not participating fully in retirement planning and not as comfortable as men in seeking financial advice and also reveals that education plays an important role in the financial literacy of women and there is a need for workshops and seminars on money management and investing are needed. Variables used for the study were Demographic factors, investment decisions and services of financial advisor.

Prajakta Joshi (2013) tries to understand financial literacy and its importance and to understand the current financial literacy initiatives that are taking place in India and other parts of the world in her paper the way of Financial Capability is through financial literacy: Indian and Global Scenario. Her study is based on descriptive analysis and for that she used secondary data from world economic forum, books and journals. The study concluded that in India financial literacy is now on the positive side. The Reserve Bank of India, Commercial Banks, SHGs, NGOs and the government had taken a lot initiative in this field but still coordinated efforts required because majority of the population still lives on day to day earning and are not able to think about savings and investments.

V. Mathivathani and Dr.M. Velumani (2014) conducted a study on Financial Literacy among Rural Women in Tamilnadu; the purpose of the study was to know the level of financial literacy among women in rural areas of Tamilnadu and concluded that financial literacy of marginalized rural women is very low. Study suggests that development of financial literacy would help the women for making better financial decisions, proper utilization of financial services and products. It would also help in wealth accumulation and financial wellbeing which lead to their personal development as well as social development.

Chijwani. M. et al. (2014) conducted a study of financial literacy among working women in Pune. The objective of study is to find out the most popular \& preferred investment instruments. The study is conducted on working women in Pune, between age group of 20-40 and who are at least graduate. Study is empirical based on survey method and sample was conducted on a random basis. The study found that the most popular investment avenue among the females interviewed is systematic investment plan.

Zulfiqar. M. (2015) conducted a study on women's economic empowerment through financial literacy, financial attitude and financial wellbeing. The objective of the study is to assess the level of financial literacy, financial attitude and financial wellbeing of working women and to examine the relationship between financial literacy, financial attitude, financial wellbeing and economic empowerment of working women. Study is conducted on 300 working women of nonfinancial sector of Pakistan. Study found that the financial literacy, financial attitude and financial wellbeing are significantly \& positively related with economic empowerment.

Pratisha Padmasri Deka (2015) tries to study the relationship between women empowerment and financial inclusion and financial literacy in her paper financial literacy and financial inclusion for women empowerment: A study. The study concludes that financial inclusion and financial literacy is a great step towards achieving women empowerment. But to achieve this, the government has to provide a environment in which banks are free to practice the necessary innovations to reach the low income women without losing their profit.

Akshita Arora (2016) conducted a study on Assessment of Financial Literacy among working Indian women; purpose of the study was to assess the financial literacy level of women. The study was conducted on 700 working women of urban areas of Rajasthan among which only 444 women responded. Three parameters i.e. financial knowledge, financial behavior and financial attitude were used to assess the level of financial literacy and found that the general awareness about financial planning tools and techniques among women remains poor. The study concluded that women are better in terms of financial attitude and behaviour as compared to financial knowledge.

\section{Financial Literacy in India}

Financial literacy and financial inclusion are two facets of an efficient economy and ensures financial stability in a country. Financial inclusion is on priority in our country and the government has made various strategies on financial inclusion in which various schemes are introduced and awareness campaigns are being held from time to time. Financial inclusion focuses on quantity where more emphasis is on creating more bank accounts at zero balance in to order to provide ease in access of basic banking facilities whereas financial literacy is more about quality where emphasis is on expanding the knowledge on financial matters and products. Financially literate person are more likely to explore the financial products/ services which was offered by various banks and can use them effectively for 
their benefits.

The Reserve Bank of India launched an initiative in 2007 to establish Financial Literacy and Credit Counseling Centers throughout the country that offer free financial education and counseling to both urban and rural populations.

In April 2012, Visa released the results of its financial literacy survey which was conducted between February and April 2012 with 25,500 participants in 28 countries. The Financial Literacy Survey revealed that Brazil had the highest level of financial literacy at $50.4 \%$ of the respondents followed by Mexico at $47.8 \%$, Australia $-46.3 \%$ and USA with $44 \%$. India was ranked 23 rd in the report with only $35 \%$ of Indian respondents as financially literate (Visa's International Financial Literacy Survey, 2012).

As per the survey conducted by the financial service giant VISA in the year 2012 Indian women was ranked on $19^{\text {th }}$ with only $36.8 \%$ of Indian respondents as financially literate. Survey was conducted between February and April 2012 with 25,500 participants in 27 countries. The Financial Literacy Survey revealed that women in Brazil had the highest level of financial literacy at $50.2 \%$, followed by Australia $-48.8 \%$, Mexico at $47.8 \%$, and USA with $44.6 \%$.

Survey revealed that $37.9 \%$ women in India followed the household budget in comparison with Brazil which had the highest rate of $51.8 \%$. Further, India ranked on $13^{\text {th }}$ with $31.3 \%$ women only who save for an emergency among 27 countries. Another survey conducted Standard \& Poor's among 1, 50,000 adults from 140 countries, only $14 \%$ Indian adults were able to answer the questions on risk diversification, where only $51 \%$ understood the concept of compound interest and $56 \%$ were answer correctly on inflation.

\section{WOMEN'S OVERALL RANKING BY COUNTRY (Most financially literate,left to right.)}

HIGHLIGHTS: Women in Brazil topped the field in overall rankings, with Australia, Mexico, the

United States and New Zealand rounding out the Top 5. Interestingly,women's overall rankings in

Brazil were slightly lower than men's, slightly higher in Mexico and New Zealand, virtually identical in the U.S., and significantly higher in Australia.

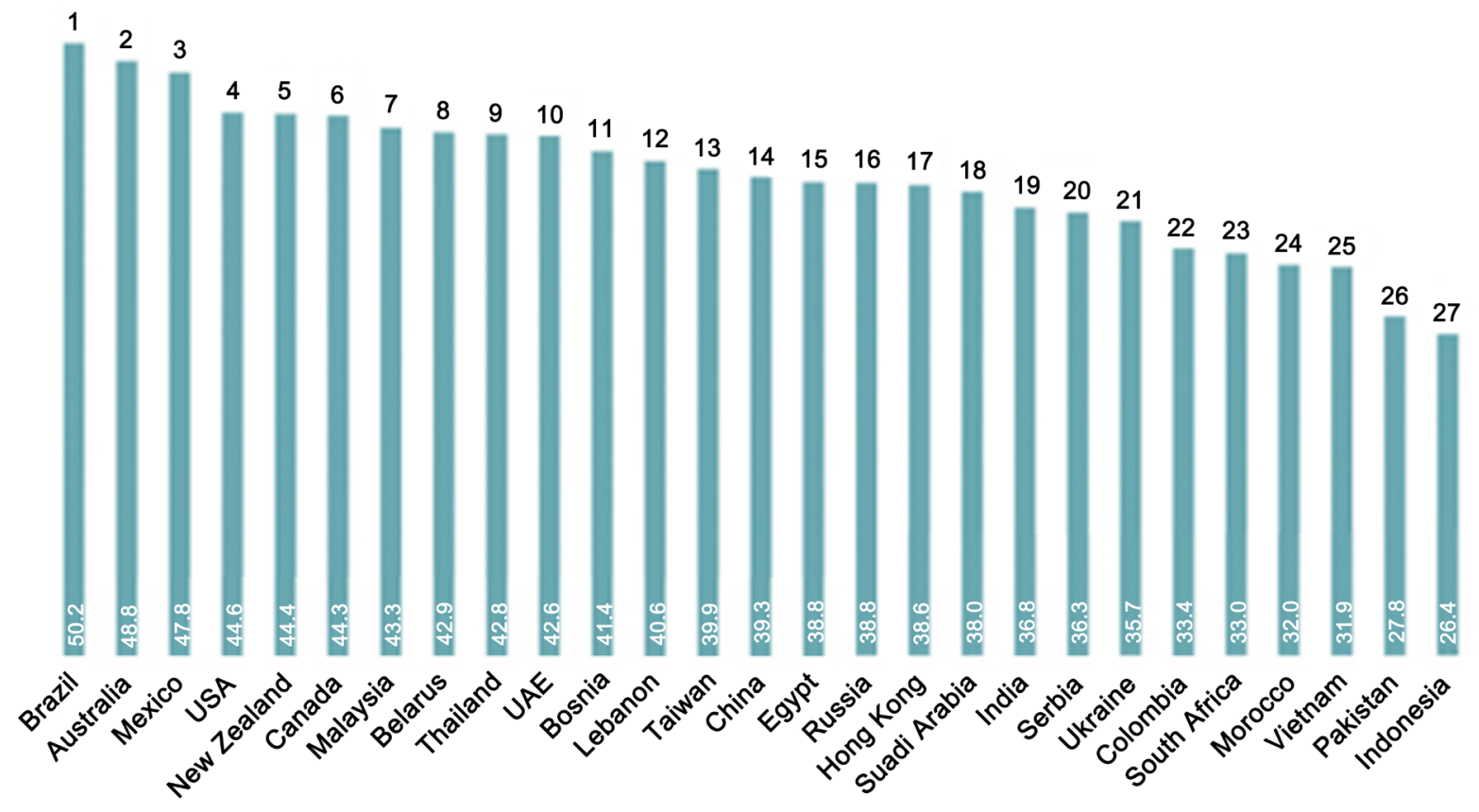

The overall country scoring is a 0-100 index bosed on the five individual 0-100 scores for budgeting (25\%), emergency savings (25\%), frequency in talking to children about money (25\%), perception of young peoples' money skills (12.5\%), and the desired age to begin formal personal finance lessons (12.5\%). 


\section{Efforts Made in the Field of Financial Literacy}

\subsection{RBI'S Initiatives on Financial Literacy}

The Reserve Bank of India has undertaken a project titled "Project Financial Literacy". The Objective of the project is to disseminate information regarding the central bank and general banking concepts to various target groups, including, school and college going children, women, rural and urban poor, defense personnel and senior citizens. The project has two modules, first module is focused on the economy, functioning and activities of RBI and second module is focused on the general banking functions. The Bank on its web site has also created a link to facilitate easy access to information for the common people; the information is available in 13 regional languages which helps people in their dealings with banks.

\subsection{SEBI's Initiatives in the Field of Financial Literacy}

Securities and Exchange Board of India (1992) has designed different modules in their financial literacy program at different segments like financial education at school level, at college level. They have different modules for executives, home makers and middle income group. SEBI has their resource person who have the knowledge of financial markets on different aspects and these executives organize different workshops for making aware of basic financial matters like savings, investments, insurance, retirement planning etc to all the target group.

\subsection{IRDA'S Initiatives in the Field of Financial Literacy}

Insurance Regulatory and Development Authority Act (1999) has taken various initiatives in the field of financial literacy. They conducted different awareness programs and circulated simple messages about the rights and duties of policyholders through television and radio channels. IRDA conducts an annual seminar on policy holder protection and welfare, and also publishes the "policyholder Handbooks" as well as various comic series on insurance.

\subsection{Initiatives by other Banks}

Apart from the Reserve Bank of India and other commercial banks, the private banks and multinational banks also do their effort to boost the financial literacy. The initiative in opening FLCCs in the country such as initiative of Bank of India, "ABHAY"e Counselling centre and Disha Trust, an initiative of ICICI Bank Ltd. Many other Banks are reaching out to the financially excluded in at least three modes, separately or in combination. "Sarthee" Bank of India's Programme is "Abhay" and Canara Bank Mobile Van called "Canara Gramina Vikas Vahini" while Dena Bank named its programme as "Dena Mitra", Allahabad Bank has named its programme as "Samadhan" (Hemanath, 2012).

\subsection{Initiatives by Non-Government Organisation (NGO)}

Non-Government Organisations started financial literacy programme as a part of their Self Help Groups development programme. The Mangalore based Institutions started a programme named "Jnana Jyothi Financial Literacy and Credit Counselling Trust" which was jointly sponsored by Syndicate Bank and Vijaya Bank. People's Education and Development Organisation (PEDO), Durgapur. Rajasthan, IBTADA, Alwar, Rajasthan, Centre for Community Economics and Development Consultants Society (CECOEDECON).

\section{Barriers to Financial Literacy among Women}

\subsection{Education}

One of the biggest problems of our nation is low literacy rate. In 2015 , the world literacy was $86.3 \%$, among which $82.7 \%$ of women were literate. The Indian scenario is bit grim where among 72\% literate persons, $65.46 \%$ women were literate whereas $82.14 \%$ men were literate. Moreover, literacy rate among urban women were $79.01 \%$ whereas only $57.09 \%$ rural women were literate. Due to lack of basic education the numerical abilities among women are poor which restrict them to analyze the financial information properly caused poor financial planning which ultimately affects their saving \& investment decisions and the wellbeing of the family as whole. Moreover, Lack of higher education among women creates problem in understanding the basic concepts of financial literacy like computation of compound interest, analysis of inflation, risk \& return trade off and portfolio diversification etc.

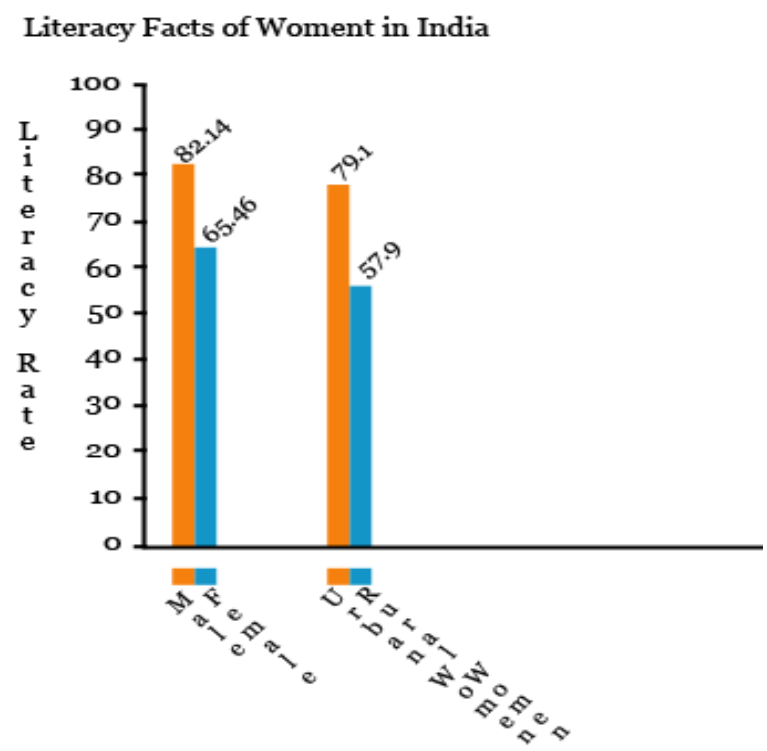

*Literacy rates relate to the population aged 7 years \& above

(Source: Census of India 2011) 


\subsection{Social and Cultural}

Since ages, this world has been a male dominated world, where men run the society and women follow him. Specially earning capacity has been the main source of power for the men to run the society. These women, not only play an important role socially, but economically also. In India, virtually women are the main spender of the family whereas the men are the principal earner of the family. Today, we are in the era where women are at par with men but still the women who were working outside were not accepted socially, they were treated as irresponsible regarding their in-laws, husband or their children. Moreover, even when they are working they were not having any right to use their earned money according to their own choices because in Indian culture the decision making lies only in the hands of male member of the family. Because of all these social and culture pressure the women in spite of having knowledge and talent were not able to prove themselves which ultimately creates problem in their empowerment socially as well as economically. Although women's access to financial services has increased substantially faster in the past 10 years, their ability to exploit this access is often still limited by the disadvantages they experience because of their gender.

\subsection{What If Factor}

Another challenge to women is the "what if' factor. Women's lack of confidence and knowledge with regard to money management affects their capability to achieve their financial potential. There is a fear among women that if they ask questions relating to their financial matters, they will be treated as uneducated or uninformed. In addition to this there is a fear among them that the process is so complex that they will not understand well or not able to access the information related to financial matters. Moreover, they were not consulting any financial adviser who can help them in making their financial planning in fear that they may charge more fees or may misuse their money or may cheat them. This all create hurdles in gaining the knowledge about the basic money management.

\subsection{Financial Barriers}

Majority of the women are not an earning person in a family. Even if they are working, they cannot take their financial decisions independently in their family. The money earned by them were treated as additional money which was only meant for spending on the leisure of family, hence they cannot use their own money on themselves as per their choices. Many times the poor financial condition of a family creates a reason for women to work. In all these conditions women were not free to take their own financial decisions as per their choices and because of this in spite of having eagerness to be financial literate they were not able to gain financial knowledge properly, since they don't have enough money with themselves to afford to have financial education from the institutions to get financial knowledge, attend seminars or workshops on financial matters and could not join various awareness programs on financial literacy etc.

\subsection{Physical Barriers}

Sometimes poor infrastructural facilities create a hindrance for women. Due to lack of private transport and less reliance on public transport services women were not able to attend the courses specially focused on financial education or not able to attend the awareness programs on financial education run by the government at different places. Many times, they were not using banking services on regular basis and find it frustrating and time \& cost consuming activity only because of less availability of good transport facility. Less availability of financial institutions and financial educations centre is also one of the physical barriers for women. Moreover, the greater use of computer now a day also act as a physical barrier for women because they were not very much frequent users of computers and find it very difficult to operate on the system.

\section{Suggestions to Improve Financial Literacy}

- More awareness programs should be created at different levels especially in rural and regionally backward areas regarding the basic banking services and their benefits.

- The government should ensure the reach of their various promotional programmes like "Jan Dhan Yojna" specifically to women especially living in rural and tribal areas so that the purpose of organising these promotional programmes could be achieved which is to provide basic banking facilities on a larger scale.

- The government may form the team of women only who can help the women in those areas where women cannot go outside their homes to get any type of information; so that they can also know the basic money management concepts and its importance as well as how these can help in their own financial condition and family too.

- Women must have to grab the opportunity and use the financial information available, if they really want to improve their financial literacy. To get more financial knowledge women have to attend more and more workshops, seminars, and financial management courses in their nearest place.

- In rural areas the bank must follow communication through vernacular/ regional/ local language, which may help the women to understand the information from banks; since the literacy rate among women especially in rural areas were very low.

- Government must spread the information on larger scale especially in rural and backward areas about various literacy programmes which was run exclusively 
for women, so that they may attend that programme and learn the basic numeracy which help them in their empowerment and prosperity of the family as whole since women are the backbone of every family.

- Matters related to basic finance and money related issues must be talk about among families, especially to female children so that they must understand the basic concepts of financial literacy and its importance in their future thus helping them understanding the actual meaning of empowerment since their childhood.

- Women must have to inculcate the habit of financial planning as soon as they started earning and must be clear about their long term financial goal so that they can utilise their earned money in more effective manner to secure their future and after retirement period thus ultimately helps in achieving their financial goal.

- Women must maintain a financial diary in which they can write down their weekly or monthly expenses and try to control their expenses or try to spend wisely; so that they can maintain regular savings which ultimately help them and their families in uncertain future expenditures.

\section{Conclusions}

Financial literacy among women is very low. It enables people to understand what is needed to achieve a lifestyle that is financially balanced, sustainable, ethical and responsible. It is directly related to the wellbeing of an individual and society as a whole. Financial literacy would help the women in making better financial decisions and helps in the utilization of financial products and services. It is very encouraging to see that today women are at par with men in all fields but when it comes to financial decision-making, they are still dependent on the male members of their family. In our country, where poverty and unemployment are the major problems, it is very crucial to financially literate the women to fuel the engine of growth by providing opportunities to women to contribute to economic growth. While women in developed countries proved to be better financial planners relatively, it is the women of emerging economies who have to become literate when it comes to money management issues. Though various initiatives were taken by different organisations to boost the financial literacy but still there is a need of more awareness programs which may include workshops, seminars, and financial management courses at different levels to get more financial knowledge regarding the banking services and their benefits one can attend.

\section{REFERENCES}

[1] Akshita Arora (2016). Assessment of Financial Literacy among working Indian Women, https://www.researchgate.net/publication/298790053, Article March 2016.

[1] Bahadur, L. R. (2015). Financial Literacy: The Indian Story. World, 5(3).

[2] Deka, P. P. (2015). Financial literacy and financial inclusion for women empowerment: A study. IJAR, 1(9), 145-148.

[3] Hung, A., Parker, A. M., \& Yoong, J. (2009). Defining and measuring financial literacy.

[4] Klatt, M. E. (2009). An Assessment of Women's Financial Literacy. Basılmamış Yüksek Lisans Tezi, Wisconsin-Stout Üniversitesi, Amerika Birleşik Devletleri.

[5] Prajakta Joshi (2013). The way of Financial Capability is through financial literacy: Indian and Global Scenario, Study Mode Research, Bank- Essays, Published 19th March 2013 ISBN: 978-93-5097-389-9.

[6] V. Mathivathani and Dr.M. Velumani (2014), Financial Literacy among Rural Women in Tamilnadu, INDIAN JOURNAL OF APPLIED RESEARCH, Volume: 4 | Issue: 12 | Dec 2014 | ISSN - 2249-555X.

[7] Visa's International Barometer of Women's Financial Literacy, April 17, 2013.

[8] Economic Survey 2014-15

[9] New economic policy 1991

[10] Census 2011

[11] Visa's International Financial Literacy Survey ( 2012)

[12] Financial Literacy Around the World: insights from the standard \& poor's ratings services global financial literacy survey

[13] http://articles.economictimes.indiatimes.com/2015-12-15/new s/69061685_1_adults-literacy-risk-diversification

[14] "Literacy Statistics Metadata Information Table". UNESCO Institute for Statistics. September 2015.

[15] S\&P survey, Dec 162015. 